\title{
Mixed embryonal carcinoma - teratoma cause early puberty: a case report
}

\author{
Can Thi Bich Ngoc ${ }^{1 *}$, Vu Chi Dung ${ }^{1}$, Bui Phuong Thao ${ }^{1}$, Nguyen Ngoc Khanh ${ }^{1}$, Tran Ngoc Son², \\ Hoang Ngoc Thach ${ }^{3}$, Nguyen Thi Hoan ${ }^{1}$ \\ From 8th APPES Biennial Scientific Meeting \\ Darwin, Australia. 29 October - 1 November 2014
}

\section{Introduction}

Mixed embryonal carcinoma - teratoma is defined a rare kind of germ cell tumor, especially in children. Objective: a rare case report with early puberty due to mixed embryonal carcinoma - teratoma.

\section{Subject}

A 3 year 7 month old boy presented with early puberty and adrenal tumor in National Hospital of Pediatrics.

\section{Method}

A case report.

\section{Results}

A 3 year 7 month old boy presented with enlargement of penis, acnes, pubic hair, deep voice. He admitted with his height of +2.3SDS, penis length of $6 \mathrm{~cm}$, testes volumn of $4 \mathrm{ml}$, pubic hair P2 (tanner). Abdoment ultrasound and CT scan showed adrenal tumor. Serum laboratory showed: 17 OHP 3,8 ng/ml, testosteron 32,3 nmol/l, cor-

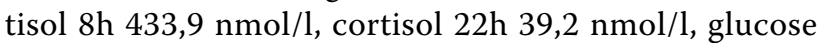
$3,7 \mathrm{mmol} / \mathrm{l}$, aFP 3945,9 u/l, electrolyte normal; urine VMA $15,5 \mu \mathrm{mol} / 24 \mathrm{~h}$; bone age 5 years. Surgical showed the tumor did not originate from the adrenal. Histologica showed mixed embryonal carcinoma - teratoma. After surgeon, the signs of virilization reduce, serum testosteron become normal.

\section{Conclusion}

Mixed embryonal carcinoma - teratoma can be caused testosterone excretion and early puberty.

Written informed consent was obtained from the patient's parent or guardian for publication of this Case

'Department of Endocrinology, Metabolism and Genetics, National Hospital of Pediatrics, Hanoi, Vietnam

Full list of author information is available at the end of the article report (and any accompanying images). A copy of the written consent is available for review by the Editor-inChief of this journal.

\section{Authors' details}

'Department of Endocrinology, Metabolism and Genetics, National Hospital of Pediatrics, Hanoi, Vietnam. ${ }^{2}$ Surgical department, National Hospital of Pediatrics, Hanoi, Vietnam. ${ }^{3}$ Anatomical department, National Hospital of Pediatrics, Hanoi, Vietnam.

Published: 28 April 2015

doi:10.1186/1687-9856-2015-S1-P93

Cite this article as: $\mathrm{Ngoc}$ et al: Mixed embryonal carcinoma - teratoma cause early puberty: a case report. International Journal of Pediatric Endocrinology 2015 2015(Suppl 1):P93.
Submit your next manuscript to BioMed Central and take full advantage of:

- Convenient online submission

- Thorough peer review

- No space constraints or color figure charges

- Immediate publication on acceptance

- Inclusion in PubMed, CAS, Scopus and Google Scholar

- Research which is freely available for redistribution

Submit your manuscript at www.biomedcentral.com/submit
() Biomed Central

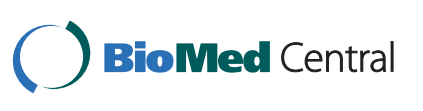

